\title{
TEOLOGI ABAD PERTENGAHAN (Teologi Skolastik) Dasar, Karakter dan Titik Berangkat
}

\author{
Alfonsus Ara*
}

\begin{abstract}
Abstrak
Kekhasan teologi abad pertengahan terletak pada sisi intrinsik budaya asali yang menjadi landasan berteologi, yaitu budaya iman kristiani sendiri (respublica christiana). Inti teologi abad ini bersumber pada misterisitas Allah sendiri. Allah mewahyukan diri-Nya dalam Putera-Nya Yesus Kristus. Dia adalah Maestro Utama dan Otoritas Tertinggi. Sabda-Nya diterima sebagai otoritas tertinggi dalam merumuskan iman Gereja.

Misteri Allah yang mewahyukan diri ini didekati, dipelajari, diklasifikasi dan didalami dalam terang iman dan kebenaran (ratio). Sisi internal yang memperlihatkan pembaharuan teologi abad ini ditemukan dalam konsep mengenai "teologi" itu sendiri, metode dan status epistemologinya. Teologi menjadi sebuah ilmu, namun bukan ilmu umum, melainkan ilmu dalam konsep teknis, yaitu cognito rei per causas (akal menjadi media untuk mencari sebab atau alasan). Sebagai sebuah ilmu yang otonom, "teologi tidak lagi menjadi perluasan sederhana dari karya eksegetis, melainkan karya yang sama sekali baru dan berbeda dari ilmu-ilmu yang lain sebab berakar pada misteri (hal-hal supranatural), obyek dari dunia iman (materinya) dan dipadukan dengan kriteria.
\end{abstract}

Kata-kata Kunci: Abad Pertengahan, Skolastik, Respublica Cristiana, Misteri, Wahyu, Iman, Kebenaran, Ilmiah, Sistematik.

\section{Pengantar}

Selama tujuh abad, teologi para bapak Gereja mewarnai seluruh aktivitas teologis Gereja. Melalui karya teologis mereka, para bapak Gereja telah mempersiapkan berbagai media kerja bagi para teolog Latin dan Yunani. Karya mengagumkan yang dihasilkan dari teologi para bapak Gereja ini adalah terciptanya peleburan antara "forma teologi"

* Alfonsus Ara, Lisensiat dalam bidang Teologi Dogmatik; lulusan Universitas Urbaniana, Italia; Dosen Teologi pada Fakultas Filsafat Unika St. Thomas, Sumatera Utara. 
dengan "forma budaya klasik" (Yunani-Romawi) di seluruh wilayah kekuasaan Romawi, baik di Timur maupun di Barat. ${ }^{1}$

Titik pemisah antara teologi para bapak Gereja dengan teologi Skolastik adalah abad VIII. Di zaman para bapak Gereja ada dua figur yang berperan penting, yaitu: Yohanes Damaskus (+ 750) di Timur dan Venerabile Beda (+ 735) di Barat. Dalam perkembangannya, muncul teologi Carolingia (abad IX). Teologi ini menjadikan "wajah budaya" sebagai media kunci bagi para teolog untuk merumuskan karya teologis yang adekuat, kukuh, teratur dan asli. ${ }^{2}$

Diakui bahwa dalam kurun waktu yang panjang ini, titik rujuk perumusan teologi Gereja selalu berbeda. Selama berabad-abad, teologi Gereja dirumuskan berdasarkan lingkup budaya Yunani-Romawi; namun pada abad pertengahan, teologi Gereja dirumuskan berdasarkan budaya Kristiani sendiri. Selama berabad-abad, teologi Gereja didominasi oleh teologi para bapak Gereja (patristik); namun pada abad pertengahan, teologi Gereja dipengaruhi sepenuhnya oleh teologi skolastik. ${ }^{3}$

Walaupun demikian, patut diakui bahwa proses penginkulturasian dasar-dasar iman kristiani ke dalam forma yang baru (forma budaya) tidak terlalu mendalam sebagaimana yang terjadi pada zaman sebelumnya. Seperti teologi para bapak Gereja, perumusan teologi Skolastik tidak terjadi dalam sekejab, tetapi dibentuk dalam fase perjalanan yang panjang dan berkembang secara perlahan. Pada fase pertama, karya teologis skolastik bertalian erat dengan teologi para bapak Gereja. Namun, pada abad X dengan dibukanya pusat dan media studi yang baru, seperti logika, ilmu-ilmu natural dan metafisik, maka secara definitif, teologi memperlihatkan corak dan rasa berteologi khas skolastik sehingga bisa dibedakan dari teologi para bapak Gereja. ${ }^{4}$

1 Battista Mondin, Storia della Teologia, Vol.2 (Bologna: Edizione Studio Domenicano, 1996), hlm. 7.

2 Battista Mondin, Storia della Teologia..., hlm. 7.

${ }^{3}$ Battista Mondin, Storia della Teologia...,hlm. 7.

${ }^{4}$ Battista Mondin, Storia della Teologia..., hlm. 7. 
Alfonsus Ara, Teologi Abad Pertengahan

\section{Teologi Skolastik dan Teologi Monastik}

Menurut para sejarahwan filsafat abad pertengahan (Hegel, Geyer, De Wulf, Vani, Rovighi, Gilson, dll), semua spekulasi filosofis-teologis yang berkembang sejak abad VIII hingga XVI berada dalam naungan nama besar Skolastik. Perkembangan ide-ide filosofis di zaman ini bisa dikapling dalam tiga fase utama, yaitu: Skolastik Awal, Skolastik Besar dan Skolastik Sesudahnya. ${ }^{5}$

Bagi ilmuwan lainnya (Leclercq, Vagaggini, dll), klasifikasi ini justru mempersempit lingkup teologis itu sendiri. Menurut mereka, teologi yang sungguh-sungguh berkembang pada abad Pertengahan ini hanya dua model utama, yaitu teologi monastik dan teologi skolastik. Teologi monastik berkembang sekitar abad XI dan XII. Muatan teologis yang terkandung di dalamnya bermuara pada doa dan kontemplasi; sedangkan teologi skolastik berkembang pada abad XIII. Muatan teologisnya bersifat sistematis dan spekulatif. 6

Untuk membuktikan kebenaran tesis ini, maka perlu diselidiki berbagai bentuk polemik yang berkembang pada zaman ini. ${ }^{7}$ Walaupun demikian, diyakini bahwa secara substansial, tesis ini mengandung kebenaran yang adekuat, sebab peralihan dari teologi para bapak Gereja ke teologi skolastik dimediasi oleh teologi monastik. Tesis ini tetap dipertahankan sebab dalam sejarah teologi, keberadaan teologi monastik tidak bisa dipastikan, apakah sungguh-sungguh berkembang selama tiga abad. Teologi monastik hanya diakui sebagai mediasi (zaman intermedia) antara teologi para bapak Gereja dengan teologi skolastik. ${ }^{8}$

Dalam sejarah teologi tercatat bahwa sejak awal kekristenan hingga abad pertengahan, yaitu masa terpanjang yang dilalui Gereja untuk merumuskan ide-ide teologisnya dibedakan hanya dua zaman, yaitu "zaman patristik dan zaman skolastik. Untuk memperjelas pembedaan

5 Battista Mondin, Storia della Teologia..., hlm. 8.

${ }^{6}$ Battista Mondin, Storia della Teologia..., hlm. 8.

7 R. Gregoire, Bulletin de Théologie Monastique", in "Studia Monastica" 10 (1968), hlm. 161-180 dan 11, 149-168; G. Penco, La Teologia Monastica. Bilancio di un Dibattito, in "Benedictina" 26 (1979), hlm. 189-198.

8 Battista Mondin, Storia della Teologia..., hlm. 8. 
kedua zaman ini, Vanni Rovighi ${ }^{9}$ menegaskan bahwa pengertian "skolastik" (yang dipergunakan dalam konteks ini) lebih merujuk pada sisi kronologis, bukan sisi metodologis dan muatan teologisnya; demikian juga dengan istilah "patristik". ${ }^{10}$

Kata patristik dipergunakan untuk mengkualifikasikan perkembangan teologi dalam kurun waktu "delapan abad pertama". Patut diakui, apabila perkembangan teologi dipertimbangkan dari sisi metodologi dan muatannya, maka ada peluang besar untuk berbicara mengenai teologi monastik, teologi aristotelian, teologi agustinian, dll. Cakupan ini patut dipertimbangkan, terutama untuk mengkarakterisasikan dan menemukan titik acuan dari dunia skolastik. ${ }^{11}$

\section{Karakter Umum Teologi Skolastik}

Ditegaskan bahwa kata "skolastik" bermakna kronologis (tidak menyingkapkan muatan teologis) sebab kata ini dipergunakan untuk mengindikasikan "teologi" yang hidup dan berkembang pada abad pertengahan dalam sejarah teologi Gereja (ekstrinsik dan intrinsik). Pada zaman Carlos Magnus (Carolingia), kata skolastik (scholasticus) sinonim dengan kata sarjana, terpelajar, berpengetahuan, orang alim, mahir, cerdik. Dalam perkembangannya, kata skolastik dipergunakan untuk memperlihatkan kolegalitas dalam "katedral", yaitu tempat bagi para calon imam untuk menimbah ilmu; sedangkan primicerius mengindikasikan sisi liturgis dan cellarius bertautan dengan sisi administrasi. Dengan demikian tampak karakter dasar dari scholasticus yang hidup dan berkembang di abad pertengahan, yaitu keterkaitan langsung antara sekolah dengan ajaran yang disajikan, baik teologi maupun filsafat. ${ }^{12}$

Kaum skolastik mencakup, baik filsuf maupun teolog. Mereka disebut kaum skolastik sebab aktivitas mereka tampak dalam ajaran yang dipaparkan di setiap sekolah dan tulisan-tulisan yang disajikan untuk

\footnotetext{
9 S. Vanni Rovighi, "Scolastica", in Enciclopedia Filosofica IV, hlm. 454-459.

10 Battista Mondin, Storia della Teologia..., hlm. 8.

11 Battista Mondin, Storia della Teologia..., hlm. 8.

12 Battista Mondin, Storia della Teologia..., hlm. 9.
} 
sekolah. ${ }^{13}$ Sedangkan sekolah kaum monastik (universitas dan para pelajar) digeluti oleh kaum monastik dan kaum klerus. Mereka berada pada posisi sekunder, sebab yang utama adalah kaum skolastik yang mendalami ilmu filsafat dan teologi. ${ }^{14}$

Namun, ada alasan yang lebih akurat untuk membenarkan aplikasi makna kata "skolastik" dalam teologi abad pertengahan.

“Disebut skolastik sebab merujuk pada sisi intrinsik budaya asali yang tersingkap di dalamnya, yaitu budaya kristiani dari respublica christiana: "Sebuah kultur iman yang mengakui bahwa akar dan dasar semua simbol, ritus, hukum, institusi, nilai, dll adalah Allah sendiri. Dia adalah Maestro Utama dan Otoritas Tertinggi. Sabda-Nya diterima sebagai otoritas tertinggi dalam merumuskan iman Gereja. Dari Allah dan Sabda Ilahi-Nya, inti kebenaran yang obyektif disampaikan kepada para Malaikat dan melalui para Nabi, para Rasul, Sabda itu digemakan kepada manusia. Sabda Allah dan inti kebenaran-Nya ini disampaikan oleh para bapak Gereja, pujangga dan doktor kepada para mahasiswa dan seluruh umat Allah. Inilah struktur hierarkis para guru yang dipanggil dan diutus untuk menyampaikan dan menjelaskan Sabda Allah. Melalui mereka inti ajaran tentang Allah dan Kebenaran-Nya yang tertuang dalam Sabda Suci-Nya dikomunikasikan kepada semua manusia yang menyatu dalam keluarga Allah. Oleh karena itu, budaya dan teologi abad pertengahan tidak hanya merujuk pada kaum skolastik, tetapi juga visi mereka tentang dunia yang terpusat pada Allah yang mencintai, memperkenalkan diri-Nya kepada manusia dan memberikan hidup-Nya, baik dalam tataran intelektual maupun moral, baik dalam tataran yuridus maupun institusi demi keselamatan manusia". 15

\section{Manfaat Teologi Skolastik}

Pada awal zaman modern, kaum humanisme dan protestanisme bersekutu untuk memisahkan diri dari Gereja Katolik. Mereka menilai bahwa Gereja dan rumusan teologisnya yang hidup dan berkembang pada abad pertengahan tidak menyentuh kehidupan real umat manusia 11.

${ }^{13} \mathrm{~J}$. Leclercq, Initiation aux auteurs Monastiques du Moyen Age (Paris 1957), hlm. 10-

${ }^{14}$ Battista Mondin, Storia della Teologia..., hlm. 9.
${ }^{15}$ Battista Mondin, Storia della Teologia..., hlm. 9. 
di dunia ini. Bagi mereka, kaum skolastik identik dengan kaum barbar: mereka merusak tatanan hidup manusia dan dimensi kemanusiaannya. Mereka juga percaya kepada takhyul dan taat buta kepada Paus. ${ }^{16}$

Diakui bahwa sejak awal Gereja, semua budaya laikal (rasionalisme, iluminisme, positivisme, liberalisme, marxisme, dll) berperan aktif untuk menyebarluaskankan prasangkah buruk mengenai kenyataan yang terjadi pada abad pertengahan. Bagi mereka, abad pertengahan merupakan periode kelam dalam kehidupan Gereja. Para teolog Gereja yang hidup di zaman ini dipandang sebagai pencari kegelapan, irasional, penuh dengan takhyul dan intoleran. Menurut mereka, dua realitas faktual yang akan senantiasa dikenang di sepanjang kehidupan manusia pada abad pertengahan ini adalah perang salib dan takhyul. ${ }^{17}$

Namun hasil studi para sejarahwan Italia, Perancis, German, dll memperlihatkan banyak nilai positif yang tersaji di abad pertengahan bagi Gereja. Mereka menjelaskan bahwa abad pertengahan merupakan masa transisi antara zaman klasik dengan zaman modern. Abad pertengahan diakui dan diterima sebagai zaman respublica christiana (christianitas) dan kultur kristen sebab pada abad ini nilai-nilai kristiani menjelma dalam semua ungkapan budaya dan struktur kehidupan sosial manusia. Di abad ini juga rahmat kodrati meragi iman kristiani di Eropa, membentuk manusia berdasarkan etnis dan budaya yang berbeda, menyatukan kultur dengan kehidupan sosial sehingga menciptakan kehidupan manusia yang mengagumkan. ${ }^{18}$

G. B. Vico menegaskan bahwa pada abad pertengahan, iman kristiani "berkilau bagi semua manusia sehingga mampu menjalani hidup yang bernas dan membahagiakan". Dalam lingkup kehidupan sosial diakui bahwa pada abad ini terjadi perpaduan yang membahagiakan dari tiga sumber utama untuk mematangkan iman Gereja, yaitu: Kristen, Klasik (Yunani-Romawi) dan spiritualitas nomaden (populasi Germania dan Slova). Perpaduan ini menjadi dasar untuk membentuk kultur baru, yaitu kultur abad pertengahan. ${ }^{19}$

\footnotetext{
${ }^{16}$ Battista Mondin, Storia della Teologia..., hlm. 10

${ }^{17}$ Battista Mondin, Storia della Teologia..., hlm. 10

${ }^{18}$ Battista Mondin, Storia della Teologia..., hlm. 10

${ }^{19}$ Battista Mondin, Storia della Teologia..., hlm. 10
} 


\section{Alfonsus Ara, Teologi Abad Pertengahan}

Buah-buah budaya kristen abad pertengahan berkelimpahan, seperti: katedral yang bermotif romanik dan gotik, halaman-halaman umum dan benteng (castelo), puisi, hukum sipil dan hukum kanonik serta karya-karya semi yang menyokong kehidupan manusia, seperti lukisan dari Cimabeu, Giotto, Beato Angelico, Komedi Ilahi karya Dante, Summa Teologi karya Thomas Aquino dan karya-karya Albertus Magnus; Hiasan bunga-bungaan karya Santo Fransiskus dan berbagai karya mengagumkan lainnya. Di hadapan orang-orang Milano, Paus Montini mengungkapkan bahwa pusaka yang diwariskan dari abad pertengahan untuk dunia sangat mengagumkan dan fantastik; warisan terindah dan penuh makna:

"Kita semua menerima warisan spiritual abad pertengahan. Kita menerima budaya dan kehidupan khas kristiani melalui simbolsimbolnya yang unik dan kaya arti. Kita dipanggil untuk menyelidiki judul-judul pusaka yang diwariskan dari zaman-zaman sebelumnya. Kita ditantang untuk membangun prinsip-prinsip dasar kehidupan demi terpupuk dan terciptanya semangat fraternitas di antara kita, invalibilitas hukum, karakter suci otoritas yang berakar dalam inti hati nurani pribadi, dari peristiwa peninggalan dan pemuliaan yang diraih melalui keletihan dan derita, dari harapan dalam kesuraman [...]. Inilah akar firasat kemanusiaan kita ... kebijaksanaan kita ... kekuatan spiritual kita ... Inilah nilai hakiki kita: iman diterangi oleh keyakinan akan suatu kepastian tatkala berhadapan dengan saudara-saudara kita dalam menghidupi Gereja Allah".20

Dalam lingkup teologis, pusaka warisan yang paling berharga dari abad pertengahan adalah format dasar berteologi yang seharusnya dikembangkan di sepanjang sejarah teologi:

"Teologi abad pertengahan dirumuskan berdasarkan kodrat budaya abad pertengahan, yaitu budaya religius khas kristen. Dalam budaya abad ini, iman bukan hanya menjadi sumber inspirasi dan nutrisi dalam seluruh aktivitas kemanusiaan dan kekristenan kita, tetapi juga memacu setiap aktivitas kita, kaum beriman untuk memperdalam inti kebenaran Iman, yaitu teologi itu sendiri. Untuk itu, para pemikir skolastik patut disederajatkan dengan para pemikir pastristik, terutama Anselmus, Bernardus, Albertus Magnus, Bonaventura, Thomas Aquino, Don Scotus. Mereka menyajikan karya besar yang sangat mengangumkan

20 "Rivista Diocesana Milanese", (1955), hlm. 9 ss. 
bagi Gereja. Karya-karya mereka berbobot sama dengan karya para Bapak Gereja, seperti Origenes, Atanasius, Gregorios Nazianze, Ambrosius, Hilarius, Agustinus". ${ }^{21}$

Berkat buah-buah pemikiran dan karya teologis kaum skolastik, tradisi asali kristen, bukan hanya diteruskan di sepanjang zaman, melainkan juga dipertahankan dan diperkaya. Iman Gereja tidak hanya diwartakan dalam budaya-budaya manusia di sepanjang masa, tetapi harus dipelihara dan dijamin kebaharuannya (diperbaharui), baik dalam wujud rumusan yang ekspresif maupun dalam totalitasnya. Skolastik memperkaya intelegensi iman (Intellectum Fidei) dalam seluruh struktur dasar teologi, terutama kristologi, angelologia (ilmu tentang Malaikat), eklesiologi dan sakramentaria. ${ }^{22}$

\section{Titik Berangkat Teologi Skolastik}

Zaman skolastik terbentang antara abad IX hingga XV (tujuh abad) dalam konteks dan situasi sosial yang berbeda. Awal teologi skolastik ditandai dengan lahirnya teologi Carolingia (abad IX) dan mencapai puncak yang menakjubkan (masa emas teologi skolastik) pada abad XVIII. Dalam perkembangannya, budaya kristen abad pertengahan, baik struktur dan institusinya mengalami krisis yang dasyat. Krisis yang berkepanjangan ini mengakhiri zaman skolastik.

Menyimak perkembangan abad ini, maka perlu digariskan bahwa teologi skolastik dibedakan dalam tiga fase utama: Fase dasar (Fase Pertama Skolastik), Fase kematangan (Fase Besar Skolastik) dan Fase Tterakhir skolastik.

\section{Tiga Fase Teologi Skolastik}

\section{Fase Pertama}

Fase pertama teologi skolastik diawali dengan lahirnya "teologi carolingia". Penamaan ini tidak hanya berkonotasi temporal (kronologi), tetapi dianalogkan dengan "Kehormatan Kaisar Carlos Magnus". "Sebagaimana konteks sosial-politik-budaya teologi carolingia seutuhnya

\footnotetext{
${ }^{21}$ Battista Mondin, Storia della Teologia..., hlm. 11.

22 Battista Mondin, Storia della Teologia..., hlm. 11.
} 
dipengaruhi oleh Kaisar Carlos Magnus, demikian juga teologi Binzantin dipengaruhi oleh Kaisar Konstantinus dan Giustiniano" ${ }^{23}$

Kreativitas dan originalitas teologi carolingia ditemukan dalam perjuangan para teolog untuk melalukan beberapa gebrakan penting, di antaranya: 24

a. Mengasimilasikan warisan-warisan klasik (tertulis) dan pemikiran para bapak Gereja dengan respek yang mendalam terhadap wilayahwilayah yang dikuasai oleh kaum Barbar melalui invasi (perebutan kekuasaan) yang keji.

b. Lahirnya teologi carolingia dilihat sebagai "derap awal perjalanan teologi dan zaman teologi yang otentik". Kebaruan dan keotentikan teologi carolingia ditemukan dalam kontaknya dengan budaya "klasik" dan "kristen" serta kekuatannya untuk memperbaharui forma teologi. Sebagai periode transisi (antara zaman patristik dan zaman modern, atau pergerakan teologi dan naskah-naskah dari abad XI dan selanjutnya), zaman carolingia diakui sebagai zaman pencerahan, bukan zaman kegelapan.

c. Zaman carolingia dianalogkan dengan zaman patristik sebab di dalamnya terkandung dua harta berharga, yaitu "warisan klasik" dan "warisan kristiani" yang bersumber pada dasar biblis dan pandangan patristik. "Di zaman ini, tradisi klasik digali kembali, terutama di kalangan kristiani. Pencarian ini tidak terbatas dalam kekayaan wawasan (gagasan), tetapi serentak menyingkapkan aksi utama untuk mengkristenisasikan Latin Baru berdasarkan takaran perkembangan budaya yang diperbaharui".

d. Karya teologi carolingia, secara langsung, dihubungkan dengan Kitab Suci Perjanjian Lama dan Perjanjian Baru: "Para teolog membaca, menggali, menafsir serta memetik makna Kitab Suci demi kehidupan beriman". Salah seorang sosok penting dalam teologi tersebut adalah Cassiodorus. Dengan ketekunan dan kesetiaan yang kukuh, dia menggali kekayaan Kitab Suci. Nilai-nilai Kitab Suci ini dipadukan dengan program hidup kaum monastik sehingga melahirkan sebuah aturan hidup yang disebut Regula Benedittina.

\footnotetext{
${ }^{23}$ Battista Mondin, Storia della Teologia..., hlm. 14

${ }^{24}$ Battista Mondin, Storia della Teologia..., hlm. 16-18.
} 
e. Karya teologis carolingia diterima dan diakui sebagai karya eksegetik. Para teolog memperkaya sistem penafsiran yang dipergunakan para bapak Gereja untuk menemukan makna ganda yang terkandung dalam teks-teks suci. Pada prinsipnya, sistem penafsiran mereka dibagi atas empat cara: "menggali dan menemukan makna biasa, makna alegoris, makna moral dan makna analogis".

- Pada tahap pertama, mereka menggali makna-makna biasa yang tersaji dalam fakta naratif Kitab Suci, yaitu sejarah narasi tersebut.

- Nilai-nilai hakiki Kitab Suci yang digali dan ditemukan ini menjadi "homili" kepada kaum beriman.

- Berbagai fakta dan makna Kitab Suci ditafsirkan dalam pemahaman figuratif dan spiritual untuk memperdalam dan meneguhkan inti iman (makna alegoris).

- Tujuan penggalian makna dan nilai-nilai Kitab Suci adalah: membantu kaum kristiani untuk menangkap, memahami dan bertindak secara moral serta menyuburkan harapan mereka berkenaan dengan kehidupan di masa yang akan datang (makna moral dan analogis). ${ }^{25}$

Mayoritas karya teologis dan karya eksegetis para teolog carolingia dirumuskan untuk menumbuhkan kepercayaan kaum beriman terhadap sumber otoritas Gereja, yaitu Kitab Suci. Oleh karena itu, obyek studi carolingia adalah misteri Wahyu Allah dalam Kitab Suci yang diterima dengan penuh kesetiaan dan ketaatan iman. ${ }^{26}$

Ini berarti bahwa dalam teologi carolingia, otoritas tertinggi adalah Allah sendiri, sehingga Kitab Suci menjadi satu-satunya sumber sebab di dalamnya termaktub Sabda-Nya sendiri. Namun, dalam karya eksegetis, otoritas Ilahi tidak terlalu tampak akibat desakan kesulitan (masa gelap) yang terjadi pada zaman ini. Karena alasan inilah, maka teologi patristik sudah menambahkan dua otoritas penting, yaitu "keputusan konsili" (magisterium) dan "ajaran para bapak Gereja". Ketiga otoritas ini, yaitu

25 A. De Lubac, Exégèse médiévale, Le Quatres Sens de l’Ecriture, (Paris 1959-1964), trad. it., Roma 1962.

${ }^{26}$ Battista Mondin, Storia della Teologia..., hlm. 17. 
"Allah, Magisterium dan para bapak Gereja" menjadi landasan berpijak para teolog carolingia dalam merumuskan ide-ide teologi mereka27.

Pada awal abad IX, Smaragdo dari Saint Mihiel menilai bahwa ada empat tokoh besar dari para bapak Gereja yang mendapat tempat utama dalam permenungan teologis Carolingia, yaitu Agustinus, Hieronimus, Ambrosius dan Gregorius. Di samping keempat tokoh besar ini, Origenes tampil sebagai "matahari baru dari dunia barat untuk menerangi alam semesta", terutama pemikiran teologis para teolog carolingia. 28

Sebagaimana biasanya, di abad terakhir teologi patristik (khususnya di timur) dan teologi carolingia, karya teologis selalu dirujukkan kepada para bapak Gereja. Penjejakan dan pendekatan teologi carolingia terhadap teologi para bapak Gereja ini terorientasi pada tataran eksegetis untuk menjamin penafsiran yang benar dan otentik terhadap isi Kitab Suci. Inti pencarian dan penggalian mereka terfokus pada misteri Allah yang mewahyukan diri dalam diri Yesus Almasih. Dengan demikian, tampak bahwa para teolog carolingia lebih menekankan dan mengutamakan nilai-nilai dogmatis yang digariskan para bapak Gereja di dalam karya-karya teologis mereka. ${ }^{29}$

Nilai-nilai dogmatis teologi carolingia digariskan menurut ketetapan para bapak Gereja, yaitu Clemens Alessandrino, Gregorius Nazianze dan Agustinus: "mereka menggali dan menemukan nilai-nilai budaya Yunani yang menjadi dasar kekristenan". Bagi mereka, semua warisan klasik merupakan kekayaan kristiani yang mampu mengarahkan kaum beriman kepada tujuannya yang benar, yaitu "kultus Allah dalam Gereja". 30

Penekanan nilai-nilai dogmatis ini dinilai sangat penting untuk menangkal rumusan teologis kaum humanis yang secara teratur dihubungkan dengan kaum kafir sebagaimana dipaparkan dalam Kitab Ulangan (21,10-13): "Kaum Israel bisa kawin dengan kaum kafir untuk

\footnotetext{
27 Battista Mondin, Storia della Teologia..., hlm. 18.

28 Notker Da Sangallo, Notatio de Illustribus Viris, PL 131, 995.

${ }^{29}$ Battista Mondin, Storia della Teologia..., hlm. 18.

${ }^{30}$ Battista Mondin, Storia della Teologia..., hlm. 18.
} 
menentukan kondisinya". Berkenaan dengan teks ini, Rabi Mauro berkomentar:

"Kita sudah biasa melakukannya dan apa yang harus kita lakukan tatkala kita membaca puisi-puisi kaum kafir; tatkala Kitab Kebijaksanaan di dunia ini jatuh ke tangan kita dan itu benar adanya. Apabila kita menemukan banyak hal yang penting, kita harus menyelidikinya dalam dogma kita. Namun, lihatlah penyembah berhala, dan kebiasaan mereka dalam banyak hal di dunia ini... jika kita menemukan banyak hal yang mubazir dan bertentangan dengan inti iman, kita tinggalkan". ${ }^{31}$

Berkenaan dengan berbagai contoh dari para bapak Gereja, para teolog carolingia menerapkan metode baru dalam menginkulturasikan iman kristiani: Sebuah inkulturasi yang mendalam sebab berakar pada media konseptual yang bersifat ortodoks dan spiritual, serta kesetiaan untuk menyebarluaskan Sabda Allah dalam Kitab Suci; setia berpegang pada suara para bapak Gereja dan seruan konsili. Tokoh- tokoh besar dari teolog carolingia adalah Alculino, Rabano Mauro dan Scoto Eriugena. Berkat kehadiran, pergumulan iman dan kerja keras mereka, teologi carolingia menemukan bentuknya, terutama untuk meneguhkan kembali warisan iman kristiani dari para bapak Gereja. ${ }^{32}$

\section{Fase Kematangan (fase besar) Skolastik}

Teologi skolastik mencapai "tahap kematangan" dengan munculnya tokoh-tokoh besar pada abad XII, seperti Abelardus, Petrus Lambardus dan Alano Lila. Ketiga tokoh ini menegaskan kembali otoritas eksegese Biblis dalam karya mereka. Walaupun demikian, di dalam merumuskan karya teologis, mereka tidak hanya membaca naskah-naskah suci (berkontemplasi, seperti dalam teologi monastik), tetapi juga membaca doktrin-doktrin suci Gereja (berbentuk kotbah, seperti dalam teologi patristik). ${ }^{33}$

Sesungguhnya, fase besar skolastik berpuncak pada abad XIII. Di masa ini, teologi dibentuk dan dirumuskan secara definitif sebagai sebuah ilmu yang otonom berkat kematangan dan kebesaran Thomas Aquino,

\footnotetext{
31 Rabanus Maurus, De Clericorum institutione III, 18 (PL 107, 396).

32 Battista Mondin, Storia della Teologia..., hlm. 18-20.

33 Battista Mondin, Storia della Teologia..., hlm. 227.
} 
Albertus Magnus, Bonaventura, Duns Scotus. Mereka menggagaskan dan merumuskan aneka karya teologis yang mengagumkan dan tiada satu formulasi teologis pun yang melampaui karya teologis mereka. Teologi di fase ini "berkarakter sistematik dan ilmiah". Karakter ini dibentuk dengan cara "memadukan karya-karya terbesar di sepanjang sejarah teologi Gereja" (Summa) sehingga membentuk sebuah rumusan yang teratur, komplet dan "ilmiah" mengenai kebenaran iman Gereja. ${ }^{34}$

Sistematik dan ilmiah merupakan ciri utama yang membedakan teologi skolastik dari teologi patristik dan teologi skolastik fase pertama. Pada fase ini, kursus-kursus teologi dikembangkan, diperluas dan diperdalam. Materi teologi yang digodok dan didalami berpusat pada Allah yang mewahyukan diri dalam terang iman dan kebenaran (ratio). ${ }^{35}$

Dalam teologi patristik dan teologi di fase pertama skolastik, wahyuiman (fides qua) menempati prioritas absolut daripada misterikebenaran (fides quae) yang diwahyukan. Pada fase besar skolastik ini prioritas dipusatkan pada misteri-kebenaran (fides quae) sehingga obyekobyek khusus pewahyuan, yaitu misteri-misteri khusus dan kebenaran tunggal didekati dan dipelajari, diklasifikasi dan ditetapkan dalam dirinya "dengan senantiasa membaca dan memperdalam aspek rencana keselamatan Allah". 36

Lingkup kerja teologis pun mengalami perubahan: aktivitas teologi tidak lagi dipusatkan dalam biara monastik atau sekolah-sekolah besar, tetapi pada universitas. Orang-orang yang ingin mengetahui dan memperdalam pelajaran teologi tidak wajib menjadi anggota benediktin atau agustinian seperti yang terjadi pada abad XII. Pada Fase besar skolastik ini karya teologis diperuntukkan bagi semua manusia, terutama orang-orang kecil (pengemis, orang miskin) sehingga banyak teolog abad XIII keluar dari ordo Dominikan dan Fransiskan. Elemen penting lainnya yang memperlihatkan karakter dasar teologi abad XIII ini adalah proses asimilasi inti pemikiran aristotelian, baik dalam tingkatan maupun formanya. ${ }^{37}$

\footnotetext{
${ }^{34}$ Battista Mondin, Storia della Teologia..., hlm. 227

35 Battista Mondin, Storia della Teologia..., hlm. 227.

${ }^{36}$ M. Schamus - A. Grillmeier - L. Scheffszyk - M. Seybold, Storia della Dottrine Cristiane. La Rivelazione, (Palermo 1992), hlm. 154-155.

${ }^{37}$ Battista Mondin, Storia della Teologia..., hlm. 227-228.
} 
Berdasarkan pada prinsip berteologi, teologi skolastik di fase besar ini bisa dibedakan atas karya teologis yang dihasilkan di universitas dan di luar universitas; berkarakter ilmiah dan sistematik, dengan menggunakan forma positif aristotelian (Filsafat Aristoteles). Secara umum, karya teologis di fase ini berkarakter summa. ${ }^{38}$

\section{Perumusan Ilmu Teologi dan Epistemologi}

Faktor-faktor intern yang memperlihatkan pembaharuan teologi di kalangan kaum skolastik ditemukan dalam konsep mengenai "teologi" itu sendiri, metode dan status epistemologinya. Pada abad XIII, teologi menjadi sebuah ilmu, namun bukan ilmu umum, melainkan ilmu dalam konsep teknis, yaitu cognito rei per causas (akal menjadi media untuk mencari sebab atau alasan). ${ }^{39}$

Sesungguhnya, prakarsa untuk menegaskan teologi sebagai sebuah ilmu yang otonom sudah dimulai sejak abad XII (momen persemaian teologi sebagai sebuah pengetahuan yang otonom). Namun, efektivitasnya sebagai sebuah ilmu yang otonom hingga mencapai tingkat kematangannya yang utuh dan sempurna baru terjadi pada abad XIII. "Diakui bahwa peralihan dan pembaharuan formulasi teologis sebagai ilmu terwujud dengan cara mengelaborasikan secara jelas dan menakjubkan antara teologi dengan epistemologinya. Momen ini dipertimbangkan sebagai nilai berharga yang diperoleh dari budaya abad XIII sehingga teologi menemukan bentuknya yang otentik dan dipertahankan tanpa keraguan di sepanjang abad". ${ }^{40}$

M. D. Chenu berkomentar, "Karya teologis abad pertengahan, terutama abad XII dan XIII secara progresif beralih dari bentuk dialektika kepada sebuah ilmu [...]. Ini merupakan sebuah perubahan besar dan menakjubkan dari dialektika, kesahajaan seni liberal trivium, yang belum menemukan bentuknya secara definitif, dari sebuah teknik perpaduan verbal dan konseptual kepada sebuah filosofi roh yang dirumuskan secara rasional. Peralihan ini menyingkapkan kedalaman pengetahuan manusia dan dunia. Pentingnya wawasan klasik, terutama landasan berpikir aristotelian menjadi ciri hakiki yang mewarnai isi permenungan teologis pada abad XIII dan akhirnya ditutup pada abad

38 Battista Mondin, Storia della Teologia..., hlm. 228.
${ }^{39}$ Battista Mondin, Storia della Teologia..., hlm. 243.
40 Battista Mondin, Storia della Teologia..., hlm. 243. 
XVI". ${ }^{41}$ "Perkembangan yang dasyat dan menakjubkan ini merupakan aplikasi nyata dari rumusan antik anselmian tentang pentingnya filsafat dalam teologi dengan rumusannya yang khas, "fides quaerens intellectum". Patut diakui bahwa pengaruh filsafat dalam teologi, terutama semangat dan pola filosofis aristotelian berpuncak dalam karya Thomas Aquino. Karya ini melampaui sejarah profesional teologi sebab episod sensasionalnya terwujud melalui pemanfaatan filsafat Aristoteles untuk merumuskan ajaran iman Gereja. Dalam perkembangannya, Santo Fransiskus dan Santo Dominikus memberikan jiwa baru bagi kelahiran rasionalitas Yunani sehingga membangkitkan kembali kegiatan evangelisasi Gereja". 42

Pada abad XII, Abelardus menamakan doktrin-doktrin suci sebagai sebuah teologi. Alano Lilla berusaha menegaskan bahwa doktrindoktrin suci ini harus dibakukan dalam aturan yang jelas dan harus diikuti hingga bisa disederajatkan dengan ilmu teologi. Diakui bahwa Abelardus dan Alano memiliki gagasan yang jelas mengenai ilmu. Walaupun demikian, mereka belum mampu mengkonsepkan dan merumuskan teologi sebagai sebuah ilmu. ${ }^{43}$

Sesungguhnya di dalam teologi itu sendiri sudah terkandung dan terkuak karakter rasional dari inti iman kristen purba. Melalui karyanya yang berjudul Stromati, Klemens dari Alessandria merekomendasikan agar kultus kristen gnostik (teologi) mempergunakan filsafat Yunani untuk menyebarluaskan doktrin kristen supaya "mampu membuktikan dan menjamin inti kebenaran yang di-Wahyu-kan, bukan sebagai konsep sederhana tentang keselamatan yang lahir dari iman [...]. Doktrin iman Gereja harus dibuktikan dan disempurnakan dengan pembuktian rasional. Untuk itu, setiap pencari inti kebijaksanaan iman harus mempergunakan elemen-elemen sederhana yang bersifat familiar sehingga mampu merumuskan dan memperlihatkan inti iman yang benar dan bisa dipertanggungjawabkan secara rasional dalam totalitasnya" ${ }^{44}$

\footnotetext{
${ }^{41}$ M.D. Chenu, La Théologie comme Science au XIII Sieècle (Paris 1957), 18.

${ }^{42}$ M.D. Chenu, La Théologie comme..., 13.

${ }^{43}$ Battista Mondin, Storia della Teologia..., hlm. 244.

${ }^{44}$ Clemente, Stromati V, 3, 18.
} 
Di dalam Didascaleion, Origenes, penerus Clemes Alessandrino menggariskan prinsip-prinsip obyektivitas secara tegas dan jelas berkenaan dengan pentingnya daya intelektual manusia dalam merumuskan inti iman. "Lakukanlah hal yang menakjubkan di mata kita dengan terang kebijaksanaan" (Os 10,12). Argumen ini menjadi landasan utama dalam berkotbah (mewartakan inti kebenaran iman) agar mampu memenuhi keinginan masing-masing pribadi yang mendambakan keteraturan, kejelasan dan pembuktian rasional di setiap argumen iman dan kebenaran serta meletakannya dalam realitas yang teratur dengan logika yang kukuh dan terpadu sehingga setiap muatan iman dalam Kitab Suci bisa dipertanggungjawabkan dengan nalar". ${ }^{45}$

Perumusan teologi spekulatif ini akhirnya dirumuskan dalam sebuah mahkota berharga karya St. Agustinus: De Doctrina Christiana. Dalam karya ini, Agustinus tidak memberikan tekanan pada keputusan iman yang penuh, tetapi pada keinginan terdalam untuk mengerti inti imannya. Agustinus menginginkan agar daya intelektualnya menjamah apa yang diimaninya. ${ }^{46}$

Pendasaran ini harus senantiasa dipegang sebab kemampuan untuk mengerti, mendalami dan berargumentasi mengenai iman dengan sendirinya menjamin mutu teologi kristen: fides quaerens intellectum (iman membutuhkan penjelasan akal, yaitu rumusan yang dipersembahkan oleh kaum anselmian). ${ }^{47}$

Abelardus, Gilberto Porretano dan Alano Lila memperlihatkan dan meneguhkan otonomi teologi dari teologi biblis. Mereka mencari dan menemukan metode (aturan) khusus, kecuali media-medianya yang secara substansial sudah ada dan dipergunakan sebelumnya, terutama ketika teologi lebih dipahami sebagai sebuah seni dalam tataran yang sederhana dan berada dalam rangkulan eksegese. 48

Abelardus, Gilberto dan Alano Lila juga memahami teologi sebagai ilmu yang "tegas" dan "teknis". "Mengacu pada karya teologis para teolog Perancis di akhir abad XII dan teologi fundamental abad XIII maka

\footnotetext{
45 Origenes, Principi, Prefazione no. 10.

46 Agustinus, PL 42, 1098.

47 Battista Mondin, Storia della Teologia..., hlm. 244.

48 Battista Mondin, Storia della Teologia..., hlm. 244-245.
} 
perlu ditegaskan bahwa teologi berada dalam cakupan "teologi positif" atau "teologi spekulatif" (istilah zaman ini). Para ilmuwan menyumbangkan gagasan mereka dengan memaparkan data-data Wahyu Allah dan menjelaskan muatannya dalam terang tradisi patristik yang melampaui diskusi filosofis mengenai makna kebenaran religius berdasarkan sistem rasional manusiawi. Metode spekulatif ini mengaplikasikan artikel iman dalam bentuk fragmentis (yang terpisah)". ${ }^{49}$

Merujuk pada landasan rasional "Aristoteles" (Barat), kandungan pemikiran "ilmiah" dan "metafisiknya" serta pola teologi para teolog Latin maka ditemukan dua hal hakiki dalam berteologi, yaitu terbuka terhadap nilai-nilai pengetahuan untuk mensistematisasikan intellectus fidei dan terbuka terhadap nilai-nilai metafisik Aristoteles untuk memperdalam misteri iman kristen. Manfaat dari landasan rasional aristotelian dalam budaya teologi abad XIII adalah:50

a. Pola teologi yang dikembangkan melampaui model tradisional (terfokus pada penafsiran kisah biblis) serta merintis cara baru dalam berteologi yang bersifat argumentatif, spekulatif dan filosofis.

b. Memperjelas status epistemologi dari sebuah teologi. "Teologi bukanlah perluasan sederhana dari karya eksegetis, melainkan karya yang sama sekali baru dan berbeda dari ilmu-ilmu yang lain sebab berakar pada misteri (hal-hal supranatural), obyek dari dunia iman (materinya) dan dipadukan dengan kriteria rasional sehingga menjadi bagian dari dunia akal sehat (formanya).

Perumusan teologi sebagai sebuah "ilmu" dan penegasan status "epistemologinya" ini tidak terjadi dalam sekejap, tetapi secara perlahan (langkah demi langkah): 51

a. Menegaskan dan mempertahankan teologi sebagai sebuah "ilmu".

b. Struktur ilmu teologi bercorak argumentatif.

${ }^{49}$ F. Van Steenberghen, Il Movimento Dottrinale nei Secoli IX-XIV, in Fliche - Martin, Storia della Chiesa, Vol. XIII (Torino 1979), hlm. 264.

${ }^{50}$ Battista Mondin, Storia della Teologia..., hlm. 245.

${ }^{51}$ Battista Mondin, Storia della Teologia..., hlm. 245-246. 
c. Sebagai sebuah ilmu, teologi mirip dengan ilmu lain, terutama struktur argumentasinya. Namun, ilmu teologi melampaui ilmu yang lain sebab menyajikan ilmu baru dengan mempergunakan nalar manusiawi.

Perumusan (pembentukan) teologi sebagai sebuah ilmu dan penegasan status epistemologinya ini merupakan peristiwa besar yang mengisi seluruh aktivitas teologi di awal abad XIII, terutama beberapa teolog besar: Guglielmo di Auxerre dan Rolanda da Cremona (fase pertama); Alessandro di Hales dan Oddone Rigaldo (fase kedua); Alberto Magno dan Thomas Aquino (fase ketiga).

Sebelum mempelajari orientasi studi dan posisi mereka, pada tempat pertama harus dijelaskan konsep ilmu dan kebijaksanaan serta sebabsebabnya sehingga terbentuk ilmu teologi.

Analisis seputar Sebab-sebab Teologi

Untuk memahami kompleksitas inti perdebatan yang berkembang pada pertengahan pertama abad XIII seputar hakekat ilmu teologi, maka dibutuhkan sebuah pemahaman yang jelas mengenai obyek dan lingkup karya teologis: "Apakah karya teologis itu mirip dengan Stromati yang dirumuskan oleh Clemens, Principi karya Origenes, De Trinitate karya Agustinus, Proslogion karya Anselmus, Breviloguium karya Bonaventura, Summa Theologia karya Thomas Aquino?52

Teologi diibaratkan dengan sebuah lukisan, ukiran, puisi, musik, dll. Untuk memahami aktivitas teologis dalam tataran ini, maka perlu diuji rumusan karya, sebab-sebab dan realisasinya serta mencari jalan yang tepat untuk mempertahankan pengenalan yang komplet sehingga sebab-sebabnya bisa disingkapkan. Menurut Aristoteles, sebab-sebab itu bisa diklarifikasi dalam empat pokok: materi, forma, efisiensi dan tujuan akhir. 53

Teologi bukanlah sebuah tindakan, melainkan sebuah karya; bukan hasil sebuah elaborasi, melainkan sebuah pekerjaan yang komplet, seperti karya manusiawi lainnya (statuta, puisi, pemandangan, meja,

52 Battista Mondin, Storia della Teologia..., hlm. 247.

${ }^{53}$ Battista Mondin, Storia della Teologia..., hlm. 247-248. 
rumah, gereja, gunung, dll) yang terbentuk dari empat sebab utama: materi, forma, efisiensi dan tujuan akhir. ${ }^{54}$

a. Sebab Material

Materi teologi adalah teks-teks suci (Kitab Suci dan Tradisi Apostolik): Sebab material ini disebut subiectum atau obiectum materiale quod.

b. Sebab Formal

Sebab formal merupakan aspek khusus yang dirangkum dari Kitab Suci, yaitu kredibilitas dan inteligibilitas muatan teks-teks suci; sebuah pencarian yang mendalam mengenai inteligibilitas misteri Ilahi dengan mempelajari simbol-simbolnya; menjelaskan karakter kebenaran, keilmiahan dan aturannya. Sebab yang kedua ini disebut subiectum (obiectum) formale quod.

c. Sebab efisiensi

Sebab efisiensi merupakan dasar untuk menyingkapkan sebuah karya teologis atau langkah serius untuk memperlihatkan inteligibilitas, keilmiahan dan ketetapan teks-teks suci. Secara komunal, sebab ini disebut subiectum (obiectum) formale quo.

Dalam karya teologis dilibatkan dua agen utama, yaitu iman (lingkup supranatural/lumen supranaturale fidei) dan ratio (lingkup natural/lumen naturale rationis). Iman dan ratio sangat dibutuhkan, sebab tanpa iman, maka teolog akan mengesampingkan materi dasar teologi itu sendiri (misteri yang diwahyukan) yang menjadi inti permenungan tentang wahyu Allah; tanpa ratio, materi (teks suci, misteri) dan inteligibilitas yang dicari tidak bisa dijelaskan dan tidak bisa dipertanggungjawabkan.

d. Obiectum formale (lingkup kausalitas efisiensi karya teologis) merupakan sebab-sebab strumental dari ratio, yaitu semua faktor yang bertentangan dengan intelegibilitas misteri yang diwahyukan. Semua hal supranatural bisa dikenal dengan daya manusiawi. Semuanya ini merupakan sarana metodologis bagi manusia untuk

${ }^{54}$ Battista Mondin, Storia della Teologia..., hlm. 248. 
merangkum misteri Allah sehingga kredibilitas dapat diuji dan dapat disingkapkan.

Bagi kaum aristotelian, teknik yang paling berkenan untuk merumuskan konsep-konsep teologis adalah memahami makna "cognito rei per causas". Paham ini akan mudah dimengerti apa bila kita menelusuri makna ilmu menurut Aristoteles. 55

Bagi Aristoteles, ilmu merupakan pemaparan argumentasi yang pasti, kuat dan jelas mengenai sebuah kebenaran dengan menggunakan sebuah silogisme yang bertitik-tolak dari hal-hal yang berbentuk deduktif (bukan sebuah pembuktian, intuisi, pengalaman): “Berangkat dari hal-hal yang umum kepada hal-hal yang bersifat khusus; dari kebenaran umum, kepada kebenaran khusus". ${ }^{56}$

Apa bila diapalikasikan dalam teologi, maka perumusan ilmu (rancangbangun) teologi akan menyajikan inti kebenaran yang bersifat spesifik, jelas dan akurat sebab disimpulkan dari kebenaran yang bersifat universal (deduksi ke induksi). Dalam tataran ini, ilmu teologi menempatkan pewahyuan universal ke dalam realitas kebenaran yang khusus, jelas dan tegas sehingga mudah dipahami. ${ }^{57}$

Ilmu memiliki hukum yang kaku. Menurut Aristoteles, di dalam ilmu natural terkandung prinsip-prinsip hakiki yang menyokong pemaparan segala sesuatu sehingga tampak jelas dan pasti. Prinsip-prinsip ini dikumpulkan dari nous. Prinsip-prinsip ini juga ditemukan dalam ilmu teologi. Namun, di dalam ilmu teologi, prinsip-prinsip ini menjadi obyek material dari inti kebenaran iman yang hanya bisa diterima, dimengerti dan dihayati dalam iman sebab merupakan sebuah misteri (tidak jelas). Namun ketidakjelasan prinsip-prinsip teologis ini hanya berkarakter quoad nous (bukan bersumber dari obyek material iman sendiri) sebab kebenaran iman (kebenaran yang diwahyukan) di dalam dirinya sendiri melampaui semua kejelasan yang ada. Prinsip hakiki ini tidak bisa diragukan kebenarannya sehingga serentak menjadi prinsip dasar dalam berfilsafat dan berteologi. Mengacu pada prinsip-prinsip ini, maka dapat disimpulkan bahwa elemen esensial yang terkandung

55 Battista Mondin, Storia della Teologia..., hlm. 248.
56 Battista Mondin, Storia della Teologia..., hlm. 248.
57 Battista Mondin, Storia della Teologia..., hlm. 248. 
dalam ilmu menurut Aristoteles adalah: memiliki hukum (aturan), $\mathrm{kaku} /$ keras dan obyektif sehingga dipergunakan dalam teologi. 58

Ini berarti bahwa sebagai sebuah ilmu, teologi harus memperlihatkan perpaduan yang apik, jelas dan tegas antara iman dan akal sehat. Kredibilitas ilmu teologi ditentukan oleh penerapan prinsip-prinsip akal/ratio (kebenaran rasional dalam tataran antropologis, kosmologis, etis, dll) ke dalam prinsip-prinsip iman dalam bentuk silogisme. Sampel yang cocok untuk mememperlihatkan tipikal dasar argumentasi teologi adalah sebagai berikut:

1). Yesus Kristus adalah Putera Allah yang menjelma menjadi Manusia.

2). Manusia adalah makhluk bebas.

3). Yesus adalah manusia bebas.

Premis pertama dalam silogisme ini adalah prinsip (inti) iman. Premis kedua adalah prinsip ratio (secara esensial, manusia itu makhluk bebas). Premis ketiga adalah collectio atau "kesimpulan teologis" yang ditarik dari premis pertama dan kedua: "Sebuah kebenaran tidak diungkapkan dari pewahyuan, tetapi dari refleksi rasional untuk menempatkan dan mengkaji buah-buah pengenalan/pengetahuan iman dengan daya nalar manusia (benih-benih pengetahuan manusia).

Yang keempat adalah sebab final. Lingkup ini menjadi dasar (alasan) yang memungkinkan kita berteologi. Lingkup ini sangat luas: "Bergerak dari doksologi menuju ortodoksi, dari evangelisasi kepada promosi manusiawi, dari antropologi kepada kerygma, dll".

Aristoteles membagi ilmu ke dalam dua kelompok: ilmu spekulatif (matematika, fisika, metafisika) dan ilmu etika yang terarah pada praksis (moral dan politik). Teologi masuk ke dalam lingkup yang mana? Teologi merupakan sebuah ilmu spekulatif atau teologi moral? Prinsip akhir dari teologi termasuk dalam kebenaran atau cinta?

\section{Sumbangan Aristoteles bagi Teologi}

Secara garis besar, upaya para guru di pertengahan abad XIII untuk merumuskan dan memperlihatkan epistemologi teologi dapat diringkas dalam tiga pokok penting: ${ }^{59}$

\footnotetext{
${ }^{58}$ Battista Mondin, Storia della Teologia..., hlm. 249.
} 
Pertama, membebaskan (emansipasi) teologi dari eksegese biblis sehingga lingkup karya teologi tidak hanya mengomentari isi Kitab Suci, tetapi membentuk bangunan dasar yang merangkul semua inti kebenaran Wahyu Allah (Kebenaran yang Diwahyukan) dan memberikan kajian rasional berdasarkan nilai-nilai hierarkis kebenaran itu sendiri. Penjelasan seputar inti kebenaran iman dilakukan dengan mengikuti pola teologi para bapak Gereja dan beberapa guru lainnya. Summa adalah sebuah karya baru yang dirumuskan para teolog mengenai teologi, sedangkan komentar langsung terhadap isi Kitab Suci merupakan karya para ekseget. Dialektika menjadi media dasar untuk memberikan solusi yang tepat terhadap aneka persoalan tatkala otoritas tidak bisa dipersatukan.

Kedua, para teolog yang hidup di pertengahan pertama abad XIII mampu mempertahankannya dengan mengembangkan teologi naratif dan secara optimal memperlihatkan tingkat keilmiahannya dalam argumen dan muatannya. Mereka memperjuangkan agar teologi tidak dikotori oleh ratio alami (rationes naturales). Mereka menjadikan kearifan dan mistik sebagai karakter dasar teologi sebagaimana dilakukan oleh para pengarang "teolog monastik" tanpa mengabaikan keilmiahannya.

Ketiga, untuk menjawab berbagai persoalan teologis, maka dasar-dasar kristologis dikaji untuk mengelarifikasikan posisi para guru dari pertengahan pertama abad XIII yang beraliran monofisis epistemologis. Mereka menegaskan bahwa teologi merupakan sebuah ilmu dan berciri ilmiah, namun teologi adalah ilmu eksklusif tentang iman dan secara intrinsik, tampaknya terpisah dari akal: Secara teratur, akal dimatikan oleh kekuatan iman. Inilah para guru yang hidup di pertengahan tahun 200-an: mereka tidak memperlihatkan epistemologi dalam teologi, tetapi sebuah pandangan yang bersifat monofisis: akal dilenyapkan untuk memberikan tempat "hanya pada iman" dan "rahmat Allah". Peran nalar dalam dunia iman hanya bersifat eksternal: mendahului (pengantar) dan menemani (mempertahankan iman).

${ }^{59}$ Battista Mondin, Storia della Teologia..., hlm. 249. 
Alfonsus Ara, Teologi Abad Pertengahan

\section{Fase Terakhir}

Abad XIV: Krisis Budaya Abad Pertengahan dan Teologi Baru

Berkenaan dengan krisis yang terjadi pada abad pertengahan, terutama dalam lingkup politik-religius, maka akan dipaparkan secara singkat berbagai peristiwa yang terjadi: ${ }^{6}$

○ 1302 : Paus Bonifasius VIII mengeluarkan sebuah "bulla" yang berjudul Unam Sanctam dan mengekskomunikasi Bello

○ 1303 : Pengkhianatan Anagni - Paus Bonifasius VIII meninggal dunia

○ 1305 : Peralihan kekuasaan Paus dari Vatikan ke Avignone

○ 1328 : Avignone bertentangan dengan Occam

○ 1329 : Hukuman terhadap Eckhart

○ 1344 : Awal perang selama 200 tahun antara Perancis dan Inggris

- 1377 : Akhir dari kejahatan Avignone dan Tahkta kepausan di Roma diduduki oleh Paus Gregorius XI.

○ 1382 : Hukuman terhadap Wycliff.

Peristiwa-peristiwa besar yang terjadi dalam perjalanan sejarah Gereja ini sangat berpengaruh terhadap kehidupan menggereja dan perkembangan teologi. Peristiwa-peristiwa ini juga mendatangkan kegelisahan dan krisis yang mendalam terhadap kemuliaan respublica Christiana dan keagungan budaya manusia.

Sejarah menunjukkan bahwa selama abad XIV terjadi pergeseran lokasi budaya: Lingkup filsafat identik dengan teologi, politik identik dengan agama, seni identik dengan sastra, konsep religius yang kaku/kuat di setiap struktur dan aktivitas manusia diganti dengan konsep yang lebih humanis dan naturalis, dari katedral yang bergaya gotik dan summa,

${ }^{60}$ Battista Mondin, Storia della Teologia..., hlm. 473. 
kini berkembang ke arah halaman-halaman luas yang menakjubkan dan karya monografi yang berkarakter ilmiah dan filosofis. ${ }^{61}$

Dalam iklim sosial-politik, budaya dan agama yang baru menyajikan gagasan baru sehingga terjadi perubahan besar dalam respublica cristiana dan lingkup budayanya. Kini berjalan begitu cepat menuju akhir abad pertengahan dan kejatuhan skolastik.

\section{Sebab-sebab Kejatuhan Skolastik}

Berkenaan dengan penyesuaian karya teologis dan filosofis patut diakui bahwa teologi yang berkembang pada abad XIV tidak terlalu miskin melahirkan gagasan-gagasan baru. Walaupun tidak ada pemikirpemikir besar, seperti Bonaventura, Thomas Aquino dan Dun Scotus, namun para teolog yang hidup di zaman ini menjadi figur sejarah yang sangat berperan dalam perkembangan sejarah teologi Gereja, seperti Occam dan Eckhart yang menggagas lahirnya via moderna (jalan modern) dan berakhirnya via antique (jalan antik). ${ }^{62}$

Berdasarkan realitas yang terjadi dalam sejarah, maka ditemukan aneka faktor yang menyebabkan jatuhnya zaman Skolastik.

a. Faktor utama yang paling berpengaruh adalah budaya

Dunia metafisik (semua yang berbauh metafisik) yang dipengaruhi oleh pemikiran aristotelian dan platonik-agustinian ditinggalkan dan dikembangkan dua pemahaman baru, yaitu nominalisme (Occam) dan mistisisme (Eckhart). Perubahan ini menyebabkan terjadinya kemunduran dalam olah permenungan teologis, yaitu dari dunia metafisik ke dunia empiris-realis (realisme-empirisme). Dampak terburuk dari perubahan ini adalah tidak adanya keseriusan dan ketajaman dalam mengembangkan studi tentang ada dan realitas, sebab orientasi studi terarah pada sperimentalisme logika (Occam) dan mistik (Eckhart).

b. Faktor religius

Faktor religius yang sangat berpengaruh adalah: a) jatuhnya kekuasaan dan kewibawan Paus (Paus dipaksa meninggalkan dan

61 Battista Mondin, Storia della Teologia..., hlm. 473.
62 Battista Mondin, Storia della Teologia..., hlm. 474. 
menyerahkan kursi kepausannya. Tahta Paus dipindahkan ke Avignone); b) masuknya Gregorius XI ke Roma, c) menjamurnya skisma besar di Barat.

c. Faktor politik

Melemahnya kekuasaan dan kewibawan Carlos Magnus menyebabkan tidak adanya struktur politik yang mampu menjamin kesatuan dalam respublica christiana. Pada abad XIV, negara-negara besar, seperti Perancis dan Inggris serta kekuasaan Kerajaan Firenze, Milano dan Venezia memperjuangkan dan menegakkan otonomi mereka dalam lingkup pemerintahan. Kekuatan politik pemerintahan dan kerajaan-kerajaan ini justru mengancam dan melemahkan kekuatan komunitas respublica christiana.

d. Faktor sekularisasi dalam kehidupan masyarakat

Mekarnya pengaruh sekularisasi menyebabkan kehidupan sosial tidak berjalan berdasarkan prinsip-prinsip iman Gereja, tetapi menurut hukum ekonomi dan hukum politik. Hati nurani manusia (dalam lingkup moral) tidak diakui otoritasnya (otonom dan komplet) dalam menentukan keputusan iman dan moral yang sesuai dengan inti iman Gereja. ${ }^{63}$

Mengacu pada faktor-faktor tersebut, maka disimpulkan bahwa krisis dalam teologi skolastik diakibatkan oleh krisis umum dalam lingkup budaya dan religius yang berkembang pada abad pertengahan. Walaupun demikian, patut diakui bahwa di samping krisis dan kemunduran yang menyakitkan dari abad pertengahan patut dicatat aneka bentuk perkembangan yang patut dibanggakan, baik dalam lingkup filsafat maupun teologi (abad XIV). Kenyataan ini, dicatat secara jelas dalam sejarah Gereja: ${ }^{4}$

a. Perkembangan menonjol tampak dalam peleburan paham-paham yang bersifat universal (universalisme) dan obyektif sebagaimana dipaparkan secara menakjubkan dalam Summa Theologia.

${ }^{63}$ Bdk. G. De Lagarde, Alle Origini dello Spirito Laico, II. Stato e Societa nel Secoli XIII E XIV, Brescia 1965.

${ }^{64}$ H. Jedin (ed), Storia della Chiesa V/2, Milano 1975, 65. 
b. Sintesis filosofis dan teologis diganti dengan model "kritik" terhadap masalah-masalah khusus yang dihadapi.

c. Karakter dasar berteologi mengalami perubahan: "metode deduksi" diganti dengan "metode induksi". Ini berarti bahwa tekanan pokok ditempatkan pada hal-hal yang bersifat individual, konkret dan bisa dikenal tanpa media umum. Subyek pengenalan menjadi obyek yang otonom dan bernilai di dalam dirinya sendiri. Dari realitas yang individual, konkret dan otonom ini akan ditarik kesimpulan umum (induksi), bukan dari realitas yang universal dan umum ditarik kesimpulan khusus (deduksi).

d. Prioritas pengenalan diberikan pada tataran rasional sehingga teologi zaman ini menjadi sebuah bentuk kritik terhadap tradisi dan otoritas magisterial Gereja. Dengan cara ini, teori gnoseologi dan logika formal memperoleh porsi yang lebih besar.

e. Keberanian yang luar biasa pada abad selanjutnya justru ditemukan dalam lingkup logika. Pengenalan ini tidak dilihat lagi sebagai bentuk spontan dari filsafat ada sebab terfokus pada logika yang berkembang pada abad pertengahan sendiri.

Keunikan metafisika, perpaduan yang harmonis antara iman dan ratio, voluntarisme, nominalisme fideista dan positivisme merupakan wujud karya yang sangat berpengaruh dalam arus permenungan teologi baru pada abad XIV. Karya-karya ini menjadi sebab kunci jatuhnya teologi skolastik. Karakter dasar teologi baru ini tidak hanya dikenal melalui daya kritiknya yang mampu meruntuhkan struktur teologi yang dibangun oleh para guru di masa emas skolastik, tetapi serentak memberikan kekuatan dan membuka jalan baru dalam menempatkan dan menentukan aneka bentuk persoalan secara baru serta memberikan jawaban-jawaban baru dan segar atas berbagai persoalan spiritual pada saat itu. ${ }^{65}$

“Sejak Eckhrat hingga Ruysbroeck, kaum mistik berjuang untuk memperkenalkan dimensi vertikal spiritual yang dihidupi sejak S. Gregorius Nizza dan St. Bernardus hingga Sta. Theresa dan St. Yohanes dari Salib. Nyanyian batin dan cetusan nurani mereka sungguhsungguh menggema untuk mengungkapkan keagungan Allah, sedangkan kaum humanis berusaha meletakan dan menegaskan

${ }^{65}$ Battista Mondin, Storia della Teologia..., hlm. 475. 
kembali jalan yang dibuka oleh S. Yustinus, yaitu mempertahankan konsep manusia yang digagaskan oleh stoisisme dan socratisme sebagai "bentuk persiapan", bukan sebagai bentuk pertentangan terhadap Injil".66

Pada Abad XIV, Gereja berlangkah dalam suasana derita dan sakit yang tidak terperihkan. Gerakan pembaharuan justru melahirkan aneka bentuk perdebatan, pertentangan dan sikap anti terhadap berbagai hal yang bersifat (antik): "via moderna bertentangan dengan via antiqua". Menanggapi situasi ini, Paus menegaskan hak temporalnya dengan mengekskomunikasikan Raja Filippo Bello dan pejabat pemerintahan, Ludovicus Bavaro serta menegaskan para teolog baru, yaitu Occam, Marsilio Padova, Eckhart, Wycliff sebagai heresi. Tindakan Paus ini semakin memacu semangat para penggagas via moderna untuk menolak via antique sebab di mata mereka, via antiqua lebih menekankan sisi rasional. ${ }^{67}$

Penggagas via moderna adalah Giulielmo Occam. Namun, patut dicatat bahwa aksi kritik terhadap via antique sesungguhnya digagas oleh seorang Dominikan, San Parciano dan seorang Fransiskan, Pietro Aurelio. ${ }^{68}$

Situasi ini semakin memburuk pada abad XIV sebab tatanan politikreligius mendukung budaya dan teologi kristen masuk ke alam krisis yang menyakitkan. Media-media diskusi yang marak diperdebatkan berkutat seputar prinsip dasar (harmonia antara iman dan akal), metode (argumentasi ilmiah) dan muatan teologi via antique yang digagas oleh Albertus Magnus, Thomas Aquino, Bonnaventura dan Dun Scotus. Pada prinsipnya, derap awal via moderna yang diprakarsai Occam dan muridmuridnya hanya berupaya menyempurnakan muatan teologi skolastik tanpa menggantikan dan merekonstruksikan kembali kebajikan dengan cara baru. Pertentangan terjadi tatkala mereka menolak bentuk mistik teologi skolastik (abad XIV) serta berusaha mencari dan mempertahankan inti kebenaran yang diwahyukan. Bagi mereka, dalam tataran mistik-rasional tidak ditemukan ortodoksi iman yang adekuat.

${ }^{66}$ A. Forest - F. Van Steenbergen - M. Gandillas, Il Movimento Dottrinale nei Secoli IX-XIV, Vol. XIII dikutip dari Fliche - Martin, Storia della Chiesa, Vol. XIII (Torino 1979), 460

67 Battista Mondin, Storia della Teologia..., hlm. 475.

${ }^{68}$ Battista Mondin, Storia della Teologia..., hlm. 475. 
Persoalan dipertajam sebab Abad XIV memberikan solusi yang salah dalam memperbaharui teologi skolastik sehingga terbentuk budaya dan cara baru dalam berteologi. Walaupun demikian, harta berharga dari teologi skolastik di fase besar tidak akan lenyap. ${ }^{69}$

$$
===0000====
$$

\section{DAFTAR PUSTAKA}

Forest, A - Van Steenbergen, F - Gandillas, M. Il Movimento Dottrinale nei Secoli IX-XIV, Vol. XIII dikutip dari Fliche - Martin, Storia della Chiesa, Vol. XIII (Torino 1979), 460

Gregoiro, R. Bulletin de Théologie Monastique", in "Studia Monastica" 10 (1968, 161-180 dan 11, 149-168.

Penco, G. La Teologia Monastica. Bilancio di un Dibattito, in "Benedictina" 26 (1979), 189-198.

Vanni Rovighi, S. “Scolastica”, in Enciclopedia Filosofica IV, 454-459.

Leclerco, J, Initiation aux auteurs Monastiques du Moyen Age (Paris 1957), 10-11.

“Rivista Diocesana Milanese", 1955, 9 ss.

De Lubac, A. Exégèse médiévale, Le Quatres Sens de l'Ecriture, Paris 19591964, trad. it., Roma 1962.

Da Sagallo, Notker. Notatio de Illustribus Viris, PL 131, 995.

${ }^{69}$ Battista Mondin, Storia della Teologia..., hlm. 475. 
Alfonsus Ara, Teologi Abad Pertengahan

Mondin, Battista, Storia della Teologia (Bologna, Edizioni Studi Domenicano, 1996)

Maurus, Rabanus Maurus. De Clericorum institutione III, 18 (PL 107, 396).

Schamus, M. - Grillmeier, A. - Scheffszyk, L. - M, Seybold. Storia della Dottrine Cristiane. La Rivelazione, Palermo 1992, 154-155.

Chenu, M.D. La Théologie comme Science au XIII Sieècle, Paris 1957, 18.

Clemente, Stromati V, 3, 18.

Origenes, Principi, Prefazione no. 10.

Agustinus, PL 42, 1098.

Van Steenberghen, F. Il Movimento Dottrinale nei Secoli IX-XIV, in Fliche Martin, Storia della Chiesa, Vol. XIII, Torino 1979, 264.

De Lagarde, G. Alle Origini dello Spirito Laico, II. Stato e Societa nel Secoli XIII E XIV, Brescia 1965.

Jedin (ed), H. Storia della Chiesa V/2, Milano 1975, 65. 